\title{
A Case Study on Management of Rett Syndrome by Wholistic approach
}

\author{
Case Report
}

\section{Renu Rathi1 $^{*}$, Bharat Rathi², Rakesh Khatana ${ }^{3}$, Suraj Sankh ${ }^{3}$}

\author{
1. Professor, Department of Kaumarbhritya, 2. Professor, Department of Rasashastra Avum Bhasajaykalpna \\ 3. PG Scholars, Department of Kaumarbhritya, \\ Mahatma Gandhi Ayurved College Hospital \& Research Centre, Salod, Wardha (Maharashtra)
}

\begin{abstract}
Background: Rett syndrome-RS comes under Autism spectrum disorder-ASD which is a neurodevelopmental syndrome. It is diagnosed by the main differentiating features of lack of interpersonal and communication skills, poor eye contact, delayed speech with pervasive abnormal body movements. Aim and Objectives: This case report is aimed at dissemination of comprehensive role of Ayurveda in management of ASD, Rett syndrome. Material and Methods: RS is the severe form of ASD. This case study of 2.3 year's girl presented with RS and global delay, being treated with wholistic approach. It comprises Ayurveda chikitsa and other therapies like Yoga, hydrotherapy, occupational, music, physiotherapy and many more. Observation and Result: Patient has shown promising results in all developmental milestones such as gross motor, fine motor and personal social in 6 months duration except language. Different varieties of massage therapy, diet and Basti, Nasya (Panchkarma) procedures, Omkar mantra chanting, passive Yogasana were done. Conclusion: In this case report, mainly Ayurveda interventions were implemented with wholistic approach as an adjuvant, received good result in gross motor development which is very difficult in RS, hence it is a unique case. It also opened the door of wholistic approach with the hope to deliver the good result in similar disorders.
\end{abstract}

Key Words: Autism spectrum disorder-ASD, Developmental and Speech delay, Rett syndrome, Wholistic approach, Other therapies, Panchakarama, Yoga, Communication.

\section{Introduction}

Rett syndrome (RS) comes under the classification of Autism spectrum disorders. It is a X linked dominant, progressive neurodevelopmental disorder, prevalence of 1:10,000 ratio, resulting from genetic mutation of the MECP2 gene. (1) ASDs are increasing drastically, may be due to adoption of western lifestyle, stress, prenatal maternal infections/ complications, faulty diet and daily regimen.(2) The definite cause is not known but many environmental predisposing factors are responsible for the occurrence of this disease. It can be correlated with Unmad as per Ayurveda to some extent as Vata is the controller of mind and in both the diseases, vitiation of mind is common. Unmad is an umbrella term for every defective psyche, described in Brihattrayee-Ayurved classics in detail. Charak has described five typesVataj, Pittaj, Kaphaj, Sannipataj and Agaantuj Unmad. (3) RS is a severe form of ASDs. The clinical features include many complex symptoms such as behavioral problems, screaming, developmental delay, mood,

\section{* Corresponding Author:}

\section{Renu Rathi}

Professor, Department of Kaumarbhritya,

Mahatma Gandhi Ayurved College Hospital \&

Research Centre,

Salod Wardha (Maharashtra) India

Email Id: renu.rathi@dmimsu.edu.in anxiety disorder, obsessive-compulsive disorder, gastrointestinal upset, jadatva/mental retardness, phobia, sleeplessness etc. The disease starts with developmental delay and the symptom of not responding to family members or peers (social isolation). Patient may feel comfort in awkward posture for long time with stereotype hand writhing movements. (4) Autistic Spectrum disorder- ASDs can be classified as Asperger syndrome, Rett syndrome, Pervasive developmental disorder-PDD, Childhood disintegrative disorder- CDD. (5) Necessary investigations may help to rule out hidden associated features and differential diagnosis, such as Karyotyping, DNA analysis, Pet scan, STARCH test (Sexually Transmitted Disease, Toxoplasmosis, AIDS, Rubella, Cytomegalo and Herpes infection), thyroid profile, CBC, EEG, IQ test etc. DSM-V diagnostic criteria is helpful in making the diagnosis of ASD, mainly based on typical clinical features, examination and history. (6) Samprapti - the probable etio-pathogenesis is based on defective organogenesis; brain damage, metabolic changes in intra-uterine life may be due to genetic predisposition, radiation, dushivisha sevan and other known or unknown reasons. It is a Tridoshaj vyadhi with variation in their dominance such as Kaphaj, Vataj, Pittaj or Dwidoshaj or Sannipataj category (7). In contemporary science, the available management is based on supportive and symptomatic treatment modalities such as physiotherapy, occupational, speech therapy, behavioral and play therapy with need-based medicines. (8) 


\section{Aim \& Objective}

Exposition of role of Ayurveda interventions with wholistic approach in the management of RS.

\section{Case Report}

Parents approached with a 2.3 years old girl child with the complaints of delayed milestones such as unable to recognize parents, drooling of saliva, speech delay since age of 6-7 months; unable to sit, stand \& walk without support with repeated abnormal movements. She had lack of appetite, irregular bowel with hard stool, poor eye contact and bilateral squint. Child had poor social smile and was not sitting till 14 months of age also. After physiotherapy, child was able to sit with support at the age of 18-20 months momentarily but no improvement was seen in other milestones. Parents underwent treatment from many hospitals but no satisfactory result was seen. In birth history, mother was having history of stress at work place and positive TORCH infection (Cytomegalo, Rubella) before conception with non-consanguineous history. In Natal history, Full Term Vaginal Delivery, Birth weight $2.200 \mathrm{~kg}$, cried soon after birth. In Post Natal history, she had given NICU care just after the delivery for observation due to peripheral cyanosis. She had received all vaccines as per routine and optional schedule. Family history was insignificant. Her sleep was disturbed with teeth grinding habit. The developmental history is delayed, reflected in table no. 1.

Table no 1: Showing developmental history at a glance in pre and post treatment $(t / t)$

\begin{tabular}{|c|c|c|c|}
\hline $\begin{array}{l}\text { Sl. } \\
\text { No }\end{array}$ & $\begin{array}{l}\text { Param } \\
\text { eters }\end{array}$ & Milestones & Achievement \\
\hline \multirow[t]{3}{*}{1} & \multirow[t]{3}{*}{$\begin{array}{l}\text { Gross } \\
\text { Motor }\end{array}$} & $\begin{array}{l}\text { Neck } \\
\text { holding }\end{array}$ & Achieved at 6 months \\
\hline & & $\begin{array}{l}\text { Sitting with } \\
\text { support }\end{array}$ & $\begin{array}{l}\text { Achieved at } 20 \text { months } \\
\text { with forward bending, } \\
\text { post treatment sitting } \\
\text { without support for long } \\
\text { period also }\end{array}$ \\
\hline & & $\begin{array}{l}\text { Standing, } \\
\text { walking } \\
\text { with } \\
\text { support }\end{array}$ & $\begin{array}{l}\text { Post } t / t \text { achieved } \\
\text { standing and walking } \\
\text { for few steps with } \\
\text { support only. }\end{array}$ \\
\hline \multirow[t]{2}{*}{2} & \multirow[t]{2}{*}{$\begin{array}{l}\text { Fine } \\
\text { motor }\end{array}$} & $\begin{array}{l}\text { Pincer } \\
\text { grasp }\end{array}$ & Not achieved yet \\
\hline & & $\begin{array}{l}\text { Reaching } \\
\text { \& holding } \\
\text { object }\end{array}$ & $\begin{array}{l}\text { Achieved post } t / t \text { with } \\
\text { palmer grasp }\end{array}$ \\
\hline 3 & $\begin{array}{l}\text { Langu } \\
\text { age }\end{array}$ & Speech & $\begin{array}{l}\text { Delayed, post } t / t \text {-loud } \\
\text { screaming, able to utter } \\
2 \text { monosyllables post } t / t \\
\text { which is appreciable by } \\
\text { parents. }\end{array}$ \\
\hline 4 & $\begin{array}{l}\text { Person } \\
\text { al- } \\
\text { social }\end{array}$ & $\begin{array}{l}\text { Social } \\
\text { smile \& } \\
\text { recognizing } \\
\text { relatives } \\
\text { Eye contact }\end{array}$ & $\begin{array}{l}\text { Post } t / t \text { achieved it with } \\
\text { much understanding \& } \\
\text { thoughtful but not } \\
\text { expresses properly } \\
\text { Moody, achieved } \\
\text { momentarily after } t / t\end{array}$ \\
\hline
\end{tabular}

Figure No. 01: Showing abnormal writhing movements of extremities, Figure no-02 showing drooling of saliva and sitting with support posture.

(Before treatment)

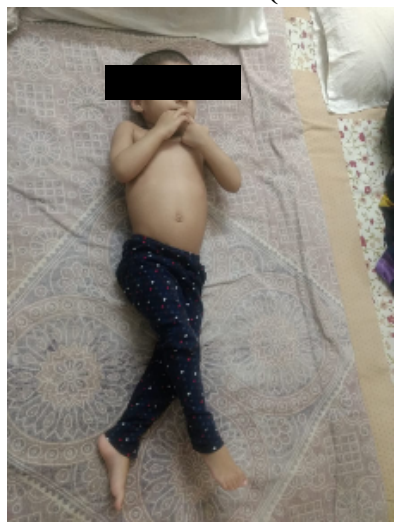

Figure No-01

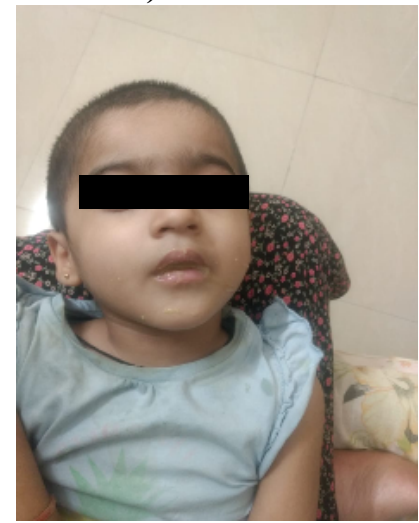

Figure No-02
On examination, pre $t / t$, she was prone to develop recurrent mild respiratory infections, but respiratory, cardiovascular system was not observed much derangements. During $t / t$, no respiratory infection occurred till 6 months and Post $\mathrm{t} / \mathrm{t}$ also no episode of any illness was noted till 8 more months. There was sluggish peristalsis hence severe constipation, lack of appetite with tendency to keep oral medicines, semisolid food bolus in the mouth for long time. Sometimes, when in mood she used to consume her favorite mashed food at average speed without difficulty in deglutition. She remained non-active with her awkward posture of all extremities writhing movements for long period without trying to communicate with others. Her general and systemic examination is depicted in table no. 2

\section{Table no 2: Showing the general \& systemic examinations findings of Rett Syndrome on admission}

\section{General Examination}

Built: -Lean

Appearance: -Lethargic

Gait: -Scissoring

Eyes: Pallor +

Tongue: Coated

Pulse rate $: 116 / \mathrm{min}$

RR:24-26/min

BP: $90 / 60 \mathrm{mmHg}$

Temperature: Normal,

Afebrile

\section{Systemic Examination}

\section{CNS-}

Conscious, but not oriented about time and place.

\section{$\downarrow$ Reflexes bilateral-}

1. Planter- flexion

2. Knee jerk- sluggish

3. Ankle jerk-sluggish

4. Biceps\& Triceps- normal

$\downarrow$ Muscle power- Grade - 3/5 of B/L Upper and lower limbs

$\downarrow$ Muscle tone- Hypotonic

$\downarrow$ CVS- S1 S2 Audible, no adventitious sound

$\downarrow$ RS- AE=BS, Chest clear

$\downarrow$ P/A-Soft, No distention or organomegaly 
Central nervous and musculoskeletal systems were grossly affected. Severity was assessed with GMFCS-(Gross motor function classification system). Her head holding and sitting was in $2^{\text {nd }}$ grade, standing0 grade, fine motor grade was 0 , personal-social grade was 1 , Ashworth scale -0 , Activities of daily living-
ADL score was 0 at the time of admission. Post treatment after $3^{\text {rd }}$ sitting, GMFCS grade of sitting -5 , standing, fine motor and Ashworth scale grade-1, Personal social and ADL score achieved 2. The anthropometry on pre-post admission is reflected in table no. 3

Table no 3: Showing the Anthropometry on pre and post treatment

On admission: -
- Weight: $9.5 \mathrm{~kg}$
- Height: $87 \mathrm{~cm}$
- Head Circumference: $44.5 \mathrm{~cm}$
- Mid Arm Circumference: $14 \mathrm{~cm}$
- BMI-12.55 Circumference: $47 \mathrm{~cm}$
PEM Grade-1

After 4 months \& 3rd sitting of treatment: -

- Weight: $10.7 \mathrm{~kg}$

- Height: $90 \mathrm{~cm}$

- Head Circumference: $45.1 \mathrm{~cm}$

- Mid Arm Circumference: $15 \mathrm{~cm}$

- Chest Circumference: $48 \mathrm{~cm}$

- BMI-12.85

- PEM Grade-1

Post treatment, constipation was relieved by Basti and there was no change in other factors. Table no. 4 is showing details of pre-post treatment status of Ashtavidha pariksha.

Table no 4: showing Ashtavidha pariksha on pre-post treatment

\begin{tabular}{|r|l|l|r|l|l|}
\hline 1 & Nadi & Kaphaj-Hansa gati & 5 & Shabda (Speech) & Cooing, screaming \\
\hline 2 & Mala(stool) & $\begin{array}{l}\text { Once in 3-6 days interval } \\
\text { Post t/t-relieved constipation }\end{array}$ & 6 & Sparsha (touch) & Sukhoshna/normal \\
\hline 3 & Mutra (urine) & $8-10$ times/day,1-2/night & 7 & Druka (vision) & Squint, no eye contact \\
\hline 4 & Jivha (tongue) & Coated & 8 & Akruti (built) & Krish/thin built \\
\hline
\end{tabular}

Post treatment, constipation was relieved with no coating on tongue but the intake of food and medicine was remained difficult, loud screaming started.

DSM-V and CARS score pre-post treatment was shown in Table no. 5

Table no. 5 depicting pre-post score of DSM-V and CARS in this RS case report

\begin{tabular}{|l|l|l|l|}
\hline S.No & Assessment criteria of DSMV \& CARS & Pre t/t score & Post t/t score \\
\hline 1 & Social Relationship- Verbal & 4 & 3 later 2 (post t/t followup) \\
2 & Impairment in communication & 4 & 3 \\
3 & Consistent attachment to some non-living objects \& its use & 4 & 3 \\
\hline 4 & Unstable \& Indecisive mind: & 4 & 2 \\
& Visual response & & \\
5 & Fear and lack of courage or Nervousness & 4 & 2 \\
6 & Total score & 20 & 12
\end{tabular}

\section{Samprapti Ghataka}

In present case Dosha involved were Kapha +++ , Vata ++ , Pitta + with all Dushya except Sweda, urine, Shukra and strotas Rasavaha to majjavah were affected. It is with bad prognosis, Asadhya-lifelong condition with main Dushti of Agni, ama and Vata-Kapha affecting whole body and mind.

\section{Probable Samprapti of Rett Syndrome}

Environmental Factor $(\mathrm{CME}$ IgG +ve $)+$ Stress during ANC + Vega Dharna
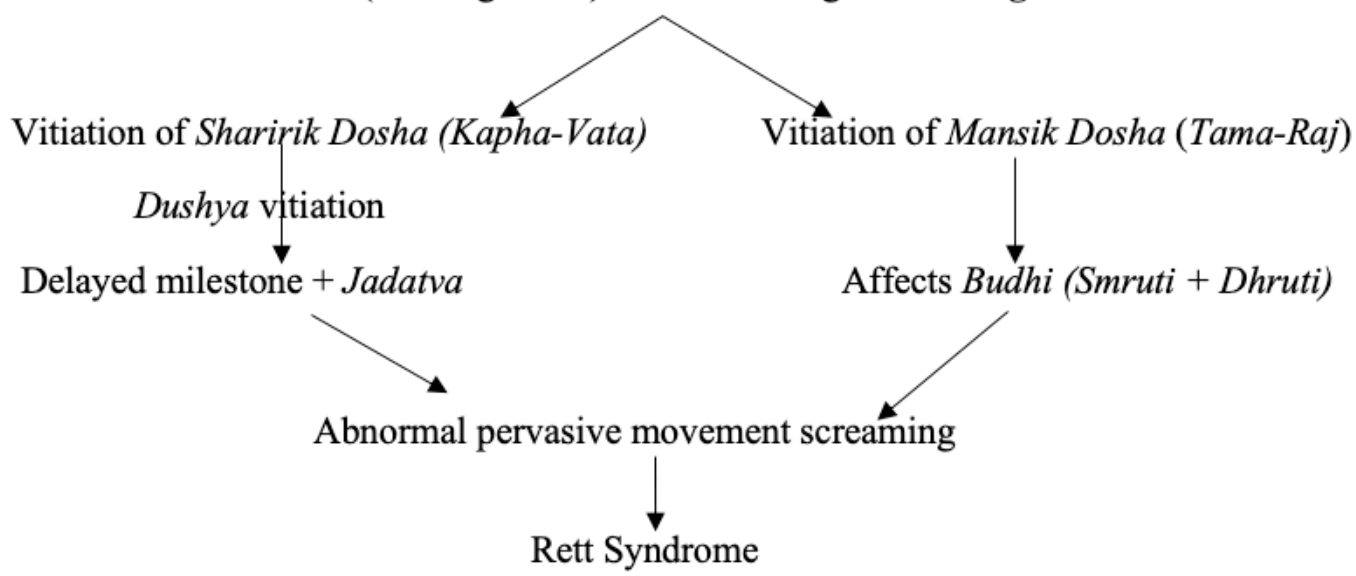


\section{Investigations}

Her LFT, KFT, CRP, CBC was normal except mild leukocytosis. In Karyotyping 46XX, presence of MECP2 gene defect. DNA and EEG were normal, MRI was showing Fronto-temoporal atrophy, Cytomegalo- Ig G was positive $(133 \mathrm{mg})$.

\section{Diagnosis}

The diagnosis of Rett Syndrome was made as per diagnostic criteria of presence of MECP2 (Methyl- CpGbinding protein 2) gene defect by molecular genetic testing which in turn leads to abnormal function of other genes too.

\section{Interventions}

As Rett syndrome is a complex syndrome with Yapya or Asadhya/not curable category hence it requires multiple interventions to improve quality of life. Ideally, all types of management modalities of AyurvedaYuktivyapashray, Daiv vyapashray \& Satvavajay chikitsa has been added in this case to improve the multiple symptoms in a short period of time due to practical difficulty of parents to stay in India and take many leaves. They also started with rehabilitative and behavioral therapy for short duration and discontinued as finding no outcome. Table no. 6 is showing the medicine details of 1 st to 3rd sitting.

Table no. 6: showing medicines administered in $1^{\text {st }}$ to $3^{\text {rd }}$ sitting: -

No.

1 Agnitundivati Ksheerbala oil-101 Avartan 10 drops tid with milk or water

2 Medhya (memory boosting) polyherbal syrup

3 Ashwagandha Ghrit

Samvardhana
Ghrita +
Suvarnaprashan

4 (KKRyog/combination) Kumarkalyanakrasa-60 mg

Praval Panchamrit $-125 \mathrm{mg}+$

Guduchi satva-100 mg

Triphla Churna-250 mg

Trikatu churna-250 mg

5 Application of Vacha + Yashtimadhu + Trikatu +Kantakari

Churna on tongue for speech stimulation

\section{Dose with duration} $3^{\text {rd }}$

$1 / 4$ th of $250 \mathrm{mg}$ twice a Warm water day(After food) x10 days

$2.5 \mathrm{ml}$ BD (After food), Water twice $\mathrm{x} 1$ month

$2.5 \mathrm{ml}$ once a day $\quad$ With Milk

(Empty stomach) for 2 months

$800 \mathrm{mg}$ twice a day x 10 With honey

days in a month

Agnitundi vati started initially as there was Agnimandya and Ama, Strotorodha present and later the condition was improved and hence withdrawn in next sittings. Kumar kalyan rasa/ KKR was continued for around 2 months out of six months treatment course intermittently. In $1^{\text {st }}$ sitting, procedures were advised as in Table no. 7

Table no.7: showing procedures performed in all the $1^{\text {st }}$ to $3^{\text {rd }}$ sitting

\section{Sr. \\ No.

$$
\begin{aligned}
& 1^{\text {st }} \text { sitting of } 10 \text { days, } 20 \text { days } \\
& \text { gap for } 2^{\text {nd }} \text { sitting }
\end{aligned}
$$

1 Nasya with Bramhi tail

\section{Shirodhara}

3 Utsadan-Udvartan (whole body) Dashmool Tail + Triphala Churna \& Triphala churna alone for Udvartana on whole body
Panchkarma Therapy

\section{$2^{\text {nd }} \& 3^{\text {rd }}$ same sitting of 21 days with gap of one month}

Bruhan-Rukshan; start \& ends with Bruhan

Brahmi Tail, 1 drop pratimarsh $x 3$ days, Rasna churna- Pradhman nasya $\mathrm{x} 3$ days alternate cycles till 21 days

Shirodhara with Brahmi tail;Vatahar $k$ wath dhara x3-3 days, alternate cycles till 21 days

Udsadan followed by Taildhara \& Udavartan followed by Kwath/kanji dhara x 3-3 days alternate Brihan \& rukshan action alternate cycles till 21 days

\section{Medicine used}

Brahmi Tail \& Rasna churna

Brahmi Tail

Dhanwantar tail + Ksheerbala tail for Tailadhara

Vatahar kwath/Kanji 


\section{Swedana}

5 Basti- started after 3 days of admission
Shashtik shali pindasweda \& patrapottali sweda, alternate 3 days each, 5 cycles till 21 days

Matrabasti-Dhanwantram Tail, $15 \mathrm{ml}$ for

3 days alternate Sasneha niruh basti with Vatahar kwath70 $\mathrm{ml}$ with saindhav, honey 5 gm each \& Dhanwantaram oil $10 \mathrm{ml} \times 3$ days alternate cycles till 21 days
With Vata shamak Kashaya (Nirgundi, Bilva, Bala, Eranda)

Dhanwantaram Tail \& vatahar kwatha
As Vata and Kapha Doshas were dominant hence Vata-kaphahar procedures were started. Application on tongue was started to stimulate speech. After $1^{\text {st }}$ sitting, her screaming, fear and undue phobia were reduced with relief in constipation. She was able to sit few more minutes without much forward bending. In $2^{\text {nd }}$ and $3^{\text {rd }}$ sitting, alternate 3 days Bruhan \& 3 days Rukshan were given to pacify both Kapha and Vata for 21 days, in which 4 cycles of Brihan procedures (Nasya by oil, Udsadan, Tailadhara, Pindswed, Matra Basti) while 3 cycles of Rukshan procedures (Pradhaman Nasya, Udvartan, Kwath Dhara, Patrapottali and Sasneha Niruh) were included. (9) In between 2 sittings there was gap of 20-30 days. Figure No-03 showing sitting in position with no drooling of saliva and Figure no. 4 depicting standing posture, post Treatment

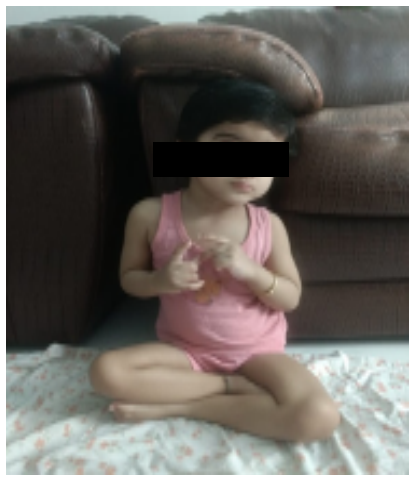

Figure No. 3: Showing sitting without support

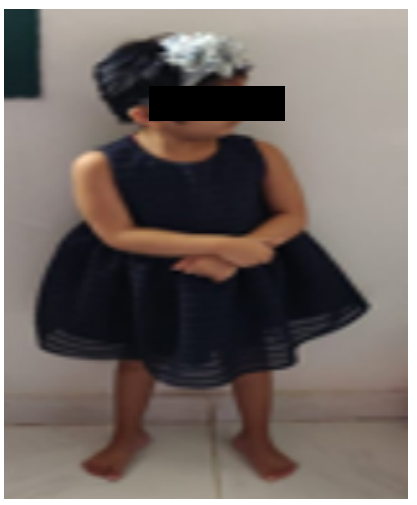

Figure No. 4: Standing posture post treatment
Multimodal treatment for the whole system correction approach such as Play therapy, counselling of parents, Physiotherapy, Occupational therapy, music therapy, hydrotherapy, touch therapy, mantra chanting and Yoga with the help of therapist and parents were beneficial to improve quality of life. CBT- cognitive behavioral therapy, Speech therapy are not possible till eye contact get improves hence not started.

\section{Discussion}

Rett syndrome is a neurodevelopmental with genetic origin but child's parents did not reveal the positive family history in both the families except work stress and untreated positive cytomegalo and Rubella infection which was probably pregestational. Rett syndrome is degenerative and has tendency to deteriorate the motor function, called as Apraxia. It occurs with idiopathic cause due to mutation in gene
MECP2, exclusively occur in females, interfering with every body movement, eye gaze and speech too. Thus, require multiple interventions to correct many complex symptoms at a time. In this case of classic RS, many autistic features were present. There was moderate positive change in pre-post treatment as per DSM V and CARS criteria (10).

Here, Kapha-vatahar medicines and procedures with other therapies were administered to check the efficacy of these Ayurveda interventions in Rett syndrome.

\section{Treatment Guideline}

As both Sharirik as well as Mansik dosha are involved in Samprapti hence multi-modal treatment approach is necessary for the whole system correction as individualized therapeutic approach (11). Starting with Yuktivyapashray Chikitsa-Agnideepan, Pachan and Anuloman was essential initial step in Rett syndrome achieved by Agnitundi ras.(12)] Sanvardhan or Bramhi Ghrit kalp- As the main centre of Vyadhi Adhishtan is brain hence any Ghrit kalp fortified with Medhya Dravyas or intake of PuranGhrit (old ghee) is very much important in treatment point of view. Kalyanak or Mahakalyanak ghrit, Panchgavya ghrit etc. also can be given. (13-14) Medhya Shamanaushadhi polyherbal syrup, Suvarnaprashan medicines to boost the action of neurotransmitters, coordination of synapse thus, augment brain function and acts as Medhya, Rasayna, Buddhivardhak (nootropic). $(15,16)$ Regarding doses, it is already described by Acharya Charak and Vagbhat that as per Agni, Koshta, Vaya, Bala, Kala etc, Vaidya has to decide the dose which may vary time to time, so as per these variations dose had changed as per need.

\section{Kumar Kalyan ras}

It provides Balya-Brihan \& Rasayan effect to enhance the function of all Dhatu, general immunity, boost growth and development of whole body and to reduce debility. It is Sukshma, Stroto gami, Pachak, Anulomak, Vatahar and Rasayan. (17)

\section{Application on tongue}

For the symptomatic treatment of saliva drooling or speech delay, Yastimadhu, Vacha, Kantakari and Trikatu mixed powder is beneficial as Vak shudddhikar yog with honey. (18) Panchkarma-Poorva karma-Rukshan, Deepan-Pachan, Snehan-swedan, \& Pre-procedures like Talapodichhil/Shirolepa, Shirodhara, Udvartan, Udsadan, Annalepan, Patrapottali, Pindasweda, Kwathdhara, Takradhara, Kanjidhara or Tailadhara etc these found to be 
effective, improve micro-circulation, eliminate toxin from skin and provides nutrients too (19). These are hot so pacify Kapha-vata both, required to tackle global developmental delay in this case. Alternate Rukshanbrihan procedures act as controlled action of Kaphavatahar. Rukshan leads to Kaphhar, Vata stimulant to activate motor function as there was quadriplegia while Bruhana- for the action of Balya-Rasayna, Medhya effect.(20,21) These help in mobilizing the deeply seated morbid Doshas from remote areas of the body to the nearest site to expel by pre-procedures and main Panchkarma procedures.

\section{Pradhan karma}

Nasya, Basti-Niruh, Matra Basti play an important role in RS. These Panchkarma specially Basti focuses on correction of metabolic disturbances, provides nutrition as well as excretes the waste products by its hot, unctuous, Vatahar properties, stimulates enteric plexus in turn central nervous system and regulates the normal functioning of not only Apan vayu but also other all types.(22) Venous drainage of rectum facilitates absorption of Basti dravya by portal circulation and then systemic circulation, thus useful in all Vatik conditions hence called as 'Ardha chikitsa'. Through Nasya, medicine directly goes to brain and stimulates its cognitive as well as sensory-motor function with correction of maladaptive behavior. (23)

\section{Paschat karma}

Sansarjan krama stimulates appetite, thereafter Balya-brihan \& Rasayan medicines effectively could act. The remaining latent Doshas were pacified by following alternative treatment modalities mentioned in table no.8. These modalities help to calm the triggering factors provoking regression of motor function and poor communication profoundly present in Rett syndrome. As in Rett Syndrome, there is reversal of motor function which patient achieves in toddler age group but after treatment we noticed a steady gain in different new milestones of gross motor, fine motor, personal-social as well as language and understanding, that is the most positive achievement of this case study. Also, gradation of DSM V features was shifted to less scoring pattern than more.

Table no.8: showing other Complementary Alternative Medicine interventions with mode of action and correlation with Ayurveda Chikitsa traya

\begin{tabular}{|l|l|l|} 
No & Name of therapy & Characteristic \\
\hline 1 & Counselling (24) & $\begin{array}{l}\text { Problem solving by } \\
\text { communication with parents } \\
\text { about tackling \& training of care }\end{array}$ \\
\hline 2 & $\begin{array}{l}\text { Yogasanas-passive } \\
\text { (26) }\end{array}$ & $\begin{array}{l}\text { Typical body postures with } \\
\text { performer's pressure }\end{array}$ \\
\hline 3 & $\begin{array}{l}\text { Omkar chanting } \\
\text { with gentle touch } \\
\text { marma therapy (27) }\end{array}$ & $\begin{array}{l}\text { Gentle touch starts from skull to } \\
\text { last part of spine, }\end{array}$ \\
\hline 4 & $\begin{array}{l}\text { Music therapy (29) } \\
\text { Instrumental light music in slow } \\
\text { volume }\end{array}$ \\
\hline 5 & $\begin{array}{l}\text { Occupational \& } \\
\text { Physio therapy } \\
\text { (30-31) }\end{array}$ & $\begin{array}{l}\text { Provide support by braces, shoes } \\
\text { \& helps muscle to move, } \\
\text { strengthen }\end{array}$ \\
\hline 6 & $\begin{array}{l}\text { Hydrotherapy (32) } \\
\text { Passive water exercises }\end{array}$ \\
\hline
\end{tabular}

Outcome

Addresses the severity of

grievances, helps to plan

management with assurance \&

positivity

Improve blood circulation, flexibility \& motor function

Offers secure and love- caring

feeling, facilitate parent-child

bonding, relieve anxiety, fear

Provides relaxation, stops

screaming, relaxes body \& mind

Improve range of motion

Ayurveda counterpart

Satvavajay

chikitsa (25)

Satvavajay, swasthavritta

Daivavyapashray

Chikitsa (28)

Daivavyapashray

Chikitsa

Yuktivyapashray

Chikitsa-YC

To boost muscle strength
$Y C$
These measures are very much beneficial in combating with complex syndromes like Rett. With multimodal and wholistic approach only there is a hope to achieve some positive results as RS is a life-long condition due to genetic origin.

\section{Conclusion}

The Autism Spectrum Disorders require the long-term interventions so as Rett syndrome also. The improvements seen after each course of management may amplify steadily. Ayurveda opens a door in the management of Autism and similar conditions and shows the spark of expectations and optimism to affected children with the help of all Chikitsa traya (Satvavajay, Yuktivyapashraya and Daiv vyapashraya chikitsa) modalities as per need.

\section{References}

1. Parthasarathy A. IAP Text Book of Paediatrics, Edition, (4th) 2009 Vol. II Jaypee Brothers Medical Publisher New Delhi, Chapter 18.2009, p. 1053

2. Kliegman, Stanton, Stgeme. Nelson Textbook of Pediatrics. Asian edition, 20th edition. Philadelphia: ELSEVIER Company, Chapter 30th Autism spectrum disorder; 2015, p177

3. Sastri Kashinath, Chaturvedi G,Editor (19thedition), Charak Samhita, Agnivesh., Chikitsasthan, Chapter 9 Verse 59, Chaukhambha Bharati Academy, Varanasi, 1993,p305

4. Ghai OP, edition( $7^{\text {th }}$ ), Ghai's Essential Pediatrics, CBS Publications 2009, p 40-41

5. Kleigmn, Behirman. Nelson text book of Pediatrics, Stanton, chapter no 33 learning disorder volume 1, 
Elsevier, Relix india Private Limited, reprint 2017, p 200

6. American Psychiatric Association. Diagnostic and Statistical Manual of Mental Disorders (Fifth ed.). Arlington, VA: American Psychiatric Publishing, 2013, p5-25

7. Acharya JT, 9th ed. Sushruta, Dalhana, Sushruta samhita, Nibandhasangraha Commentary, Uttartantra, 62/12-16 Verse 4, edited Varanasi: Chaukambha Orientalia; 2003.p 617

8. Kleigmn,Behirman. Nelson textbook of Pediatrics; 18 ed.; Saunders publishers, Philadelphia; 2008; p. 146

9. Singh R.H. Pancakrama Therapy, Edition Reprint, Chowkhamba Sanskrit Series Office Varanasi. 2007, p184-199

10. Chapter on Autism spectrum Disorders- Ayurveda approach, Karma, Jun 2020

11. Paul Mills J, Patel S. et al. Advancing Research on Traditional Whole system Medicine Approaches. Journal of Evidence based complementary \& Alternative Medicine. 2017; 22; 527-530.

12. The Ayurvedic formulary of India, part 1, $2^{\text {nd }}$ revised English edition, 2003, Ministry of health \& family welfare, Govt of India, New Delhi, 20:9, Udarrogadhikar, Rasaratnasamuccaya 20/215-217, p. 297

13. Shukla N Devangi, Shukla Vinay, Ravishankar B, Chandola HM, A Comparative Psycho NeuroPharmacological Study on Guduchyadi Ghrita \& Bhringarajadi Ghrita, AYU. Year 2007, 28; 68-76.

14. Rathi Bharat, et al. Physico- chemical analysis of Purana ghrit(old clarified butter) with special reference to fatty acid profil. J Ind. Sys Med. 2018; 6 ; 4-9

15. Ray Suman, Asim Ray. MedhyaRasayan in brain function and Disease.Medicinal Chemistry. 2015; 5; 505-511

16. Rathi R, Rathi B. Efficacy of Suvarnaprashan in Preterm infants- A Comparative Pilot study. Joinsysmed 2017; 5(2):91-97

17. The Ayurvedic formulary of India, part $1,2^{\text {nd }}$ revised English edition, Ministry of health \& family welfare, Govt of India, New Delhi, 20:9, Balrogadhikar, Bhaishjya ratnavali, 2003, p.260

18. Kute Arun et al, Role of Ayurvedic medicinal plants in childhood neuropsychiatric disorders: An Evidence based approach, International Journal of Ayurvedaa and pharma Research. 2017, 5:1-7

19. Renu Rathi, Chapter in Book on Best Practices in Panchkarma Chapter on Comparative efficacy of therapeutic Panchkarma procedures in children with Cerebral Palsy, ISBN: 978-93-5268-176-1 Publisher-Registrar, DMIMS, 2017
20. Rathi R, Rathi B, Sharma S, Rajput DS. Management of childhood Protein Energy Malnutrition through Ayurvedic interventions. Joinsysmed2017;5(3):196-202

21. Renu Bharat Rathi and Bharat Jagdish Rathi. COVID 19 Pandemic and Preventive Footsteps. Int J Ayu Pharm Chem 2020;12 (3):100-106 Vidyanath. Panchkarma. A handbook for students and practitioners. Chaukhambha Sanskrit prakashan, Delhi, 2003, p. 27

22. Agnivesh, Shastri SN, Charak Samhita, Siddhisthan, 1/53, Chaukhambha Bharti Academy, Varanasi, 19th edition, 1998, p.975

23. Bhat R K. et al. Effect of Madhookasaradi nasya in the management of positive symptoms of schizophrenia, Int. J. Ayu . Alt.Med.,2013;1(1);35-42

24. Rathi Renu et al. Behavioral problems in childrenMethod to prevent and manage through good parenting and Ayurveda. J. res.tradit.med.2017, 3(4); $117-122$

25. Tripathi JS. Dimensions of Satvavajay Chikitsa (Ayurvedaic psychothrerapy) \& their climical applications. J Annals of Ayu Med. 2012;1(1);31-38

26. Shantha Radhakrishna, Raghuram Nagarathna, and H. R. Nagendra. Integrated approach to yoga therapy and autism spectrum disorders. J-AIM. $2010 ; 1 ; 120-124$

27. Telles et al. Autonomic changes during ' OM' meditation. Indin J Physiol Pharmacol.1995;39;418-20

28. Patil pl, Bonde PW. An overview and approach towards Autism \& its management in Ayurveda. Ped Health Res. 2018, 3(1)36-42

29. Sharda $M$ et al. Music improves social communication and auditory-motor connectivity in children with autism._Transitional Psychiatry 2018; $8: 2-13$

30. Ashburner Jill, Rodger S. Occupational therapy services for people with autism spectrum disorders: Current state of play, use of evidence and future learning priorities. Australian Occupational therapy journal. 2014, 61:110-12

31. Osnat Atun-Einy OA, Lotan M. et al. Physical Therapy for Young Children Diagnosed with Autism Spectrum Disorders-Clinical Frameworks Model in an Israeli Setting. 2013; 1:19.

32. Mortimer R. et al. The effectiveness of hydrotherapy in the treatment of social and behavioral aspects of children with autism spectrum disorders: a systematic review. JMDH (Journal of Multidisciplinary Healthcare), 2014; 7: 93-104. 